\title{
DEFENDING THE WELFARE STATE
}

\section{MICHAEL BARRATT BROWN}

Economista, doctor Honoris Causa, Open University y doctor Honoris Causa en Educación, Universidad de Sheffield. Fue Principal del Northen College, desde su fundación, en 1977, a 1984. Fundador y Presidente desde 1985, de TWIN (Third World Information Network) y TWIN Trading (Comercio justo), Director de la Bertrand Russell Peace Foundation y autor de numerosas publicaciones de Economía Política, Educación y Política Social.

Este artículo procede de su libro The May Day Manifesto. Part One. Defending the Welfare State. For a working group of the Independent Labour Network. Spokesman, 1998. Nottingham.

\section{EUROPEAN COMPARISONS}

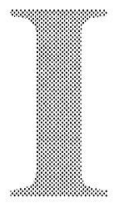

$\mathrm{f}$ there seems to be no recent rising trend in UK Government social security spending to be detected, it might be that spending in Britain has been moving ahead of that in continental countries, and that this is the cause of Mr Blair's concern to achieve savings. There are, of course, some big differences in the size and wealth and in the economic structures of the several European countries, even among those already in the European Union. Populations vary from Germany's 81 millions and the UK's 59 millions to Luxemburg's half million and Ireland's 3 '5 million. National incomes per head range almost as widely, from Switzerland and Norway's US $\$ 40,000$ a year, outside the European Union, to Greece and Portugal's US $\$ 9000$ inside the Union. The range is not so wide if incomes are measured in purchasing power parities instead of being translated into dollars according to exchange rates, but Switzerland still comes out at three times the level of Portugal and Greece.

European countries' economies have been growing at different rates. While Sweden, Finland and even Germany have had negative 'growth' rates in the last decade, Ireland, Spain and Portugal have been catching up with much higher growth rates than the average, but this cannot be said of poor little Greece. As for the UK, it will surprise many to know that at the end of years of 'growth' the UK comes very near the bottom of the pile, in the European Union only above Ireland, Spain, Portugal and Greece in income however measured. What distinguishes the UK is the yawning gap between the rich and the poor. No other country has the poorest 20 per cent of its people with less than 5 per cent of the 
incomes and only Switzerland as well as the UK has the richest 20 per cent with over 44 per cent.

Variations in the proportion of national incomes spent by governments are also very wide, and there has been some convergence here too. But the UK has been stuck in a position near to the bottom -today with only Luxemburg and Ireland having lower proportions. There has been a rising trend in government spending on average throughout Europe, but two governments -Belgium and the Netherlands as well as the UK - have cut their spending proportion since 1980. So the UK government spending spree that $\mathrm{Mr}$ Blair is seeking to cut back as quickly as possible seems not to exist, and to be relatively quite slight in the field of social protection.

The share of the national income going to social security in the UK is, moreover, well below others except for Greece and Portugal.

TABLE 1: General Government Spending, 1970, 1980, $1992-95$ and 1997.

European Countries in order of total spend per GDP, 1997

\begin{tabular}{|c|c|c|c|c|c|c|c|c|c|}
\hline \multirow{4}{*}{$\frac{\text { Country }}{\text { Sweden }}$} & \multirow{2}{*}{\multicolumn{3}{|c|}{$\begin{array}{c}\text { Public Expenditure } \\
\text { as \% pof GDP }\end{array}$}} & \multicolumn{6}{|c|}{ Shares of Central Govt. Spending $\%$} \\
\hline & & & & \multirow{2}{*}{\multicolumn{2}{|c|}{$\begin{array}{l}\text { Social Secturity } \\
19801992 / 5\end{array}$}} & \multicolumn{2}{|c|}{ Health } & \multirow{2}{*}{\multicolumn{2}{|c|}{$\begin{array}{c}\text { Education } \\
19801992 / 5\end{array}$}} \\
\hline & 1970 & 1980 & 1997 & & & 1980 & $992 / 5$ & & \\
\hline & 43.2 & 61.6 & 66.9 & 46.4 & 48.2 & 2.0 & 0.2 & 10.5 & 5.0 \\
\hline Denmark & 42.0 & 54.8 & 58.2 & 41.2 & 39.9 & 1.4 & 1.1 & 10.0 & 10.6 \\
\hline Norway & ---- & ---- & $\cdots$ & 33.5 & 39.5 & 10.3 & 10.2 & 8.5 & 9.7 \\
\hline Finland & 30.5 & 39.4 & 56.5 & 26.0 & 45.6 & 11.2 & 11.2 & 14.5 & 11.3 \\
\hline France & 38.1 & 46.6 & 53.5 & 43.9 & 45.0 & 14.7 & 15.5 & 8.3 & 7.0 \\
\hline Belgium & 41.2 & 57.4 & 53.0 & 41.6 & --- & 1.7 & $\ldots$ & 14.4 & --- \\
\hline Austria & 39.1 & 48.8 & 51.7 & 45.1 & 45.8 & 13.2 & 13.2 & 9.6 & -- \\
\hline Italy & 32.4 & 42.4 & 51.0 & 31.4 & --- & 10.8 & --- & 9.1 & -- \\
\hline Netherlands & 41.8 & 56.7 & 50.1 & 37.0 & 37.2 & 11.7 & 14.2 & 12.5 & 10.1 \\
\hline EUR II & 37.0 & 46.6 & 49.4 & $\cdots$ & --- & -- & -- & --- & -- \\
\hline Germany & 38.5 & 48.0 & 48.9 & 49.5 & -- & 19.2 & 16.8 & 0.8 & 0.8 \\
\hline Greece & -- & 27.3 & 44.9 & 30.6 & 13.4 & 10.5 & 7.4 & 9.6 & 8.5 \\
\hline Portugal & 20.2 & $\ldots$ & 44.3 & 24.6 & $\ldots$ & 10.4 & -- & 10.3 & $\ldots$ \\
\hline Spain & 21.6 & 32.9 & 43.5 & 59.0 & 39.0 & 0.6 & 6.2 & 7.7 & 4.4 \\
\hline UK & 37.3 & 43.2 & 41.3 & 28.3 & 29.6 & 13.2 & 14.0 & 2.2 & 3.3 \\
\hline Luxemburg & 30.1 & 50.3 & 40.7 & --- & $\overline{---}$ & -- & $\cdots$ & --- & -- \\
\hline Ireland & 35.5 & 47.8 & 35.2 & --- & 28.2 & -- & 14.0 & --- & 12.8 \\
\hline
\end{tabular}

Notes: Public Expenditure includes central and local spending, and public investment

Central Government spending, e.g. on Education, however, excludes local government spending. Thus UK total public spending on education in 1994 as a \% of GNP was 5.4 and Germany's was $4.8 \%$.

Social Security $=$ social security and welfare, but not housing.

Sources: "Public Expenditure" from EC, European Economy: Annual Economic Report for 1997, "Shares of Central Government Spending" from UNDP, Human Development Report, 1997, Table 35, p. 212. 
Perhaps, figures showing shares in national income give a false impression and the real increase of social spending has been faster in Britain. But this is not true either. Whether measured in real terms or in purchasing power parities, the UK from 1980 to 1994 retained its position just below the European average in expenditure on social protection.

\subsection{Costs to Industry}

Who has been feeding the Prime Minister with false information? And why? Could it be that the threats and rumours that Mr Blair says he wishes to discount are in fact being spread by his own spin doctors, that the aim is to continue the Tories' salami cuts in social provision so as to reduce employers' social costs? If so it is somewhat disingenuous for the 'road show' organisers to tell all who might think of joining that those business sponsors who are likely to gain from the reforms will not be welcome. In fact, all employers can expect to gain at the expense of labour. So what is the actual evidence of the comparative taxes and social contributions and comparative social costs which British industry bears compared with potential competitors?

Once again the story is the same. The UK lies in 13th place out of 20 in the list of countries ranked in order of taxes and social security contributions as a percentage of national income. Of the European countries, only Switzerland, Spain and Portugal come below the UK, joined here by the USA and Japan from outside Europe. Taxes on corporate profits made in the UK are equivalent to the European average and even somewhat below that of the USA and Japan. But social security contributions paid by employers in the UK, as a proportion of national income, are absolutely the lowest in Europe and less than those paid in the USA and Japan. And the difference is not slight: the European average is nearly three times what UK employers pay. Moreover, unit labour costs have been cut back further in real terms in the 1990s in the UK than anywhere else in Europe except in Italy and Finland.

What is more important for the argument about the costs of social security is that, at the last time these were compared, in 1988, the UK had the lowest proportion of indirect costs in total industry labour costs of any of the then twelve members of the European Community. Indirect costs comprise statutory and non-statutory social security, vocational training and other services paid for by the employer. Just to add to this bonanza for employers in the UK, workers put in longer hours of work in the UK than those worked anywhere else in the European Union -32 per cent working over 44 hours a week and 20 
per cent over 48 hours, compared with a European average of 15 per cent and 8 per cent respectively. The UK was, moreover, the only country where working hours were lengthened in the period recorded by Eurostat studies, between 1987 and 1991, making it the sweatshop of Europe, as Jacques Santer once implied.

\subsection{Benefit and the Incentive to Work}

How can one prove that it is lack of jobs rather than the attractions of welfare provision that determines the level of unemployment in any country or region? There is no doubt, of course, about the correlation of lack of economic activity with the provision of income support. Of 36 English and Welsh districts, in 1993, with more than 20 per cent of households receiving income support, all but eight had lower than average economic activity rates and some of them very much lower. The eight that were above the average were only just above, and were not concentrated in any particular region-Hastings, Merthyr Tydfil, Lambeth for example. Similarly, if we look at the European figures, there is no doubt also that social protection spending has risen as unemployment has risen since 1980 .

Apart from these two phenomena moving together, there appears to be no other correlation between levels of unemployment and social spending among European countries. High social spending does not necessarily go with high unemployment. Indeed, taking the three years separately, 1980, 1990 and 1994: in 1980 and 1990 the countries with highest social protection -Finland, Germany, Luxemburg- had the lowest unemployment. Only in 1994 does high unemployment go with high social protection, and the argument that high spending on social protection followed upon high unemployment, rather than the other way round, is strongly indicated by all the other reasons that are known for the rise in Scandinavian and German unemployment after 1990. In particular, there was the collapse of the Soviet market and the reunification of Germany.

Payments to the unemployed may take up as much as one tenth of all expenditure on social protection, when unemployment is high, and thus have a major influence on the size of the overall social security budget. The rising trend of unemployment throughout Europe has probably accounted largely for rising social security expenditure. The other reason for this rise is the same as in the UK, the increase in the number of old people in the population -in the European Union as a whole from 15 per cent in 1960 , to nearly 18 per cent in 1980 and over 20 per cent today. The proportion of persons of pensionable age in the UK has moved roughly in line with that elsewhere. Pensions 
TABLE 2: Social protection benefits by function, 1980 and 1994.

European Countries ranked in order of total benefits, 1994

\begin{tabular}{|c|c|c|c|c|c|c|c|c|}
\hline \multirow[b]{2}{*}{ Country } & \multicolumn{2}{|c|}{ OldAge (\%) } & \multicolumn{2}{|c|}{ Enployment (\%) } & \multicolumn{2}{|c|}{ Sickness $(\%)$} & \multicolumn{2}{|c|}{ Family $(\%)$} \\
\hline & 1980 & 1994 & 1980 & 1994 & 1980 & 1994 & 1980 & 1994 \\
\hline Denmark & 36 & 38 & 11 & 16 & 36 & 28 & 11 & 8 \\
\hline Luxemburg & 48 & 47 & 0 & 3 & 42 & 40 & 13 & 9 \\
\hline Germany & --- & 42 & --- & 8 & $-\cdots$ & 39 & --- & 3 \\
\hline France & 43 & 43 & 5 & 8 & 36 & 35 & 12 & 9 \\
\hline Netherlands & 32 & 37 & 8 & 11 & 51 & 46 & 10 & 4 \\
\hline Belgium & 41 & 44 & 12 & 11 & 35 & 35 & 11 & 8 \\
\hline $\mathrm{UK}$ & 42 & 42 & 11 & 12 & 34 & 32 & 15 & 10 \\
\hline Italy & 58 & 63 & 2 & 2 & 35 & 30 & 7 & 3 \\
\hline lreland & 31 & 27 & 9 & 12 & 44 & 38 & 12 & 13 \\
\hline Spain & 42 & 44 & 16 & 18 & 36 & 35 & 3 & 2 \\
\hline Portugal & 40 & 40 & 3 & 6 & 47 & 49 & 9 & 4 \\
\hline Greece & 67 & 68 & 2 & 2 & 27 & 24 & 1 & 1 \\
\hline
\end{tabular}

Notes: Columns do not necessarily add up to 100, because for some countries there are other functions not shown on the Table. "Old Age" includes "Survivors".

"Employment" includes employment promotion and unemployment benefits.

"Sickness" includes invalidity and occupational accidents.

"Family" includes maternity benefit.

Sources: EUROSTAT, Social Protection Expenditure and Receipts, 1980-1994, Luxemburg, 1996, Table B.6, pp. 28-29.

everywhere in Europe moved ahead faster than national incomes after 1980 , and this is largely the result of the spread of supplementary voluntary schemes, which amounted by 1993 to an additional 10 per cent on average on top of the basic pension. The UK and Ireland are distinguished, however, by the very large share of the pension accounted for by such supplementary, i.e. private, schemes -over one third in the case of the UK, something the authors of the DSS Focus file celebrate so enthusiastically.

Invalidity and sickness benefits in most European countries take the next largest proportion of social protection after old age pensions. It is the same in the UK as elsewhere. There is a suggestion in $\mathrm{Mr}$ Blair's Times article, confirmed in the Government's aim to cut back on invalidity benefit, that sickness and invalidity claims are sometimes fraudulent. They have certainly been rising in the UK, but they have not been rising much faster than national income and somewhat less rapidly in relation to national income than has been the experience in most European countries.

If only state pension provision is compared, the UK comes below even the USA and Japan at 5 per cent of national income spent in 1994, according to an article in the National Institute Economic Review, 
and that compares with over 12 per cent in France, Germany, Italy and Sweden.

\subsection{What about Fraud?}

Mr Blair refers to an estimate of between $£ 4$ and $£ 5$ billions of benefit fraud each year. But, in response, Professor Townsend quotes Baroness Hollis, in charge of the Government's 'Benefit Integrity Project', stating that they had not turned up any evidence of fraud affecting disability benefit. Mr Blair claims that more is spent on 'disability and incapacity benefits than... on the entire school system in the UK'. According to the Focus file 04, expenditure on disability and incapacity benefits rose to about $£ 12$ billion in 1995, which was almost exactly the same as was spent on schools. Thanks to the Tory Government's $£ 3$ billion proposed cuts in allowances in that year, which the DSS authors of the file euphemistically refer to as 'the changes in April 1995', expenditure will fall back in future. The fact is, however, that while the schools population has been falling, even between 1981 and 1994 from 9' 1 million to 8 ' 2 million, the numbers drawing invalidity pensions had almost doubled -from one million to two million. And, as Professor Townsend has pointed out, providing for school children's needs requires only a small part of the income of their families compared with the needs of the disabled. Spending on education should be increased -all are agreed on that- but should those with a disablity and incapacity be penalised? They are among many who are deprived of educational opportunity through lack of funding.

The UK is one of several countries in the European Union with slightly above the average proportion of over $60 \mathrm{~s}$ in the population. But the increase of 90 per cent in numbers drawing invalidity allowances and disablement pensions in the UK over the years 1980 to 1992 was not a larger percentage increase than was shown in Germany, Spain and Greece, although in France and Belgium and Portugal the increase was only around 30 per cent, and in Italy the increase in disablement allowances paid seems to have cancelled out a reduction in invalidity pensions.

What is most striking in the Eurostat reports for 1992-3 on Social Protection (Figs $1 \& 2$ ) is that, whereas the estimates of the population of disabled persons show the UK having about the average proportion of the total population with a disablement, they show that it has only half the average proportion receiving financial aid linked to a disability. Once more the UK is down with Spain and Greece, at the bottom of the league table. And since that time the cuts in allowances made by the Tory Government have come into force, including the phasing out 
FIGURE 1: Estimate of the population of disabled persons (1992)

As a percentage of the total population

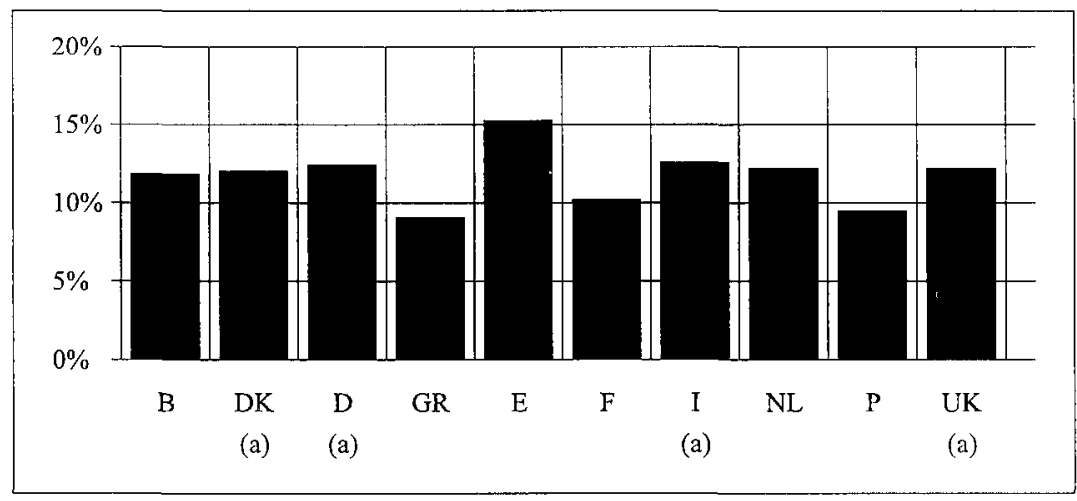

Notes: (a) 1991

FIGURE 2: Estimate of the population of disabled persons receiving financial and linked to a disability, 1991 ( $<60$ ans)

As a percentage of the total population ( $<60$ ans)

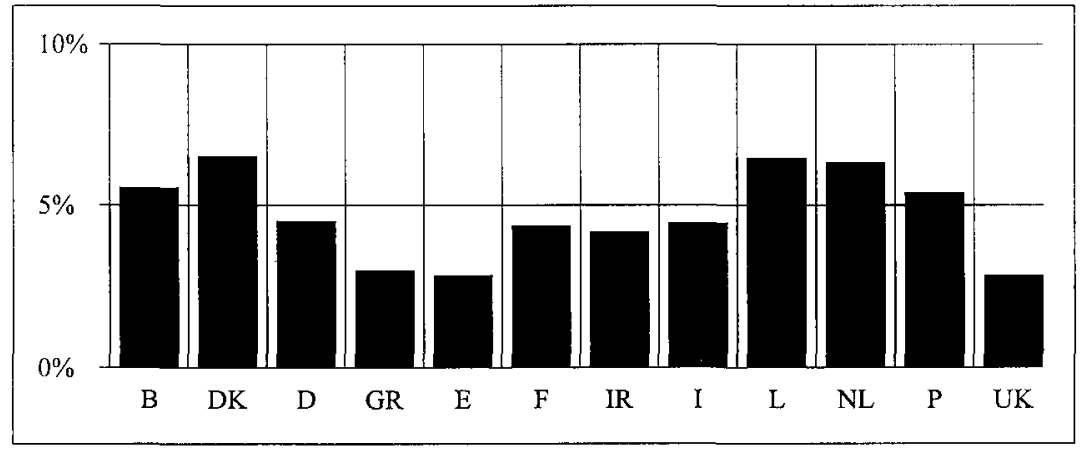

of the earnings related incapacity benefit, for which recipients had been making their contributions over many years.

In all countries, of course, those drawing war pensions have declined in numbers as old soldiers and their widows have died, but these are listed separately from disablement and invalidity. If there is fraud, as Mr Blair suspects, in the rapid increase in disability claims in the UK, then he must be claiming that it is going on also in Germany, Spain and Greece and to a lesser extent in other EU states, where numbers of claimants have been rising rapidly. And, indeed, the proportion of national income paid out in 1994 in UK sickness and invalidity benefits was below that in other countries in the European Union, except for Greece. Denmark and Italy also had lower figures, but these are accounted for by enhanced pension provision in those countries (Table 
2 above). The sharp rise in the UK in payments for sickness and disability in the years from 1991, up to the peak in 1996, when the new regulations came into force, might have been enough to make up for the UK's poor showing earlier but this must be doubted as the gap was so wide (Fig. 1); and the cuts had begun to bite in 1996 according to the DSS file.

Fraud is by its very nature hard to pin down but the evidence of Baroness Hollis quoted earlier was reassuring. The evidence on the ground concerning the results of the last Government's cut backs, now perpetuated by New Labour, suggests that much injustice is being done. Invalidity and sickness are determined by medical examination and rules can unfortunately be adjusted to meet the stringency of financial requirements. There is much evidence that men made redundant from industrial closures, and particularly from pit closures, have qualified for sickness benefit. Some may well have been 'carried' by their mates after injuries in their old jobs, but would not find a new job easily. Many will have tried and failed to find new work and applied for the higher rate of sickness benefit because of the absolute absence of alternative job creation in areas of industrial decline. This situation has been fully documented by the Coalfield Communities Campaign and reported in Ken Coates, MEP, and Michael Barratt Brown, Community under Attack: The Struggle for Survival in the Coalfield Communitt'es of Britain (Spokesman, 1997).

It would seem to be a strange way to tackle fraud to reduce the levels of social security payment. Most people faced by such reductions would seek to do everything possible to maximise their benefits. The campaign against fraud also consorts ill with Mr Blair's aim to get more money to those in need who do not now claim the income support to which they are entitled. More means testing and more inspectors will hardly encourage those who are too frightened or too ignorant to claim what is owing to them. At the root of all fraud must lie the lack of work and opportunities for work at a living wage. Create the jobs and the problem solves itself, and, as Professor Townsend has insisted, 'benefit fraud when properly investigated turns out to be much smaller than claimed, and is far smaller in total value than tax evasion and tax fraud.'

Family allowances form another benefit under attack from the salami chopper. Payments in the UK under this heading are only just above the average in value and in relation to national income, when compared with others in the European Union, but there is one big difference in the conditions for eligibility. In the UK a much larger proportion is subject to a means test than is normal elsewhere, except in Ireland. Moreover, while basic schemes have gone down in real value in the 
$U K$, down rather more than the average for the rest of the EU, the means tested proportion has risen correspondingly faster. According to the Focus files, the proportion of benefits that are means tested doubled between 1979/80 and 1995/6 from 16 per cent to 35 per cent. By contrast in Denmark and Luxemburg family benefit is more than twice what it is in the UK, and in France and Germany 50 per cent larger, and, except in Germany, almost all without means testing.

It was argued at the beginning, with authoritative support, that far from cutting child benefit the Government should greatly increase its value. This would do more than anything else to encourage women (and men too) to look for work, even at low wages, if they are not already doing so, but also provide for women who feel that they need to stay with their young children. Studies that have been made show that there is very little evidence of skiving, whatever the tabloid press may say. The Employment Services' 1992 Report, Employment in Britain, described a survey of a sample 1000 unemployed and 3000 employed people and found that commitment to work (defined as 'would work even if there was no financial necessity') was very high. It was higher among unemployed people ( 76 per cent) than among those in employment ( 68 per cent). Similar results were found in surveys made in Coalfield areas (see Community under Attack, Coates and Barratt Brown, Spokesman 1997).

\subsection{What Price Maternity?}

Maternity benefit in the UK has attracted the most criticism from the new Minister for Social Security, a mother herself. This benefit is not means tested, so that the criticism is presumably on the grounds of Mr Blair's criterion of 'spending the tax-payers' money wisely'. Since the cash benefit is paid on the basis of lost salary, one mother with an income of over $£ 1$ million was said to have been paid $£ 20,000$ in maternity benefit. The story was carefully supplied to the Murdoch press, which lapped it up as an example of the need for 'reform'. But it should surely never have been agreed that the employer should be refunded by the state for such employment costs.

In fact, as has already been emphasised, the reform needed would primarily be in the tax system, which fails to tax such grotesque incomes at higher rates, following the Tory Government's abolition of the higher rate bands, which New Labour apparently is not willing to restore. In any case the average cash benefit of all kinds for a non-retired household in the top 20 per cent of UK households is only $£ 800$ a year to add to an average original income of over $£ 40,000$. In the over $£ 1$ million a year income band, cash benefits of a few hundred pounds would not 
appear very large, and the number of such incomes among women must be very small. In fact, the Labour Research Department failed to find any such example, but did find that women earning over $£ 30,000$ a year only accounted for 5 per cent of the actual maternity payments.

There has been some talk of an affluence test, but this would not only be difficult to administer, but would be quite without effect until a serious effort is made to deal with all those tax dodges which $\mathrm{Mr}$ Gordon Brown, before he came to power, said he was going to stop. It also creates a difficult problem that already faces those who wish once more to treat partners as single tax units for tax credit schemes and thus end the woman's much treasured and only newly found financial independence.

In fact, maternity benefits as a proportion of national incomes have been declining in most European countries, but not in the UK. While the UK is among the higher spenders in Europe on maternity benefit, a far smaller proportion of this is paid in cash in the UK and a much larger proportion on hospital and other medical services than in other countries. Of course, European countries have different ways of providing hospital and other medical services, which accounts for the wide variation in cash payments.

Given that fertility rates have gone down very rapidly in Europe in the last 30 years -from 2'61 in 1960 to 1'48 in 1992 on average among the EUR 12 and from $2^{\prime} 72$ to $1^{\prime} 79$ in the UK- further reductions in maternity benefits must be regarded as inadvisable. Any rate below $2^{\prime} 0$ per female member of the population naturally implies a declining population. Some might prefer this, but it carries the implication of an ever smaller population of young people to work for an ever larger population of old people. It looks like playing to the gallery of tabloid press readers rather than serious policy making for the Government to be fussing about putting curbs on universal maternity benefit.

\section{WHAT SHOULD BE REFORMED}

Mr Blair in his Times article listed the main changes in our society to which, he believed, the welfare state must adapt: most people changing jobs at least five or six times in their career, more women at work, people living longer, up to 30 years after retirement, more marriages ending in divorce. There is no doubt about the truth of all of these assumptions except the first one, which we can look at in a footnote (p.65 below).

But Mr Blair has drawn the wrong conclusions, which we can discuss at the end, and he has missed out the most important changes 
as they affect the provision of welfare. The first is the change in the balance in our lives of paid work and leisure. The second is the crumbling framework of the nation state which has to support the welfare state. We are already beginning to see the reduction in the hours and years of paid work and the corresponding increase in the time devoted to what we call leisure activities, including studying. This process is certain to continue, in spite of the long hours that those who have paid work spend at work. Many others find themselves without work or facing early retirement. Both are at present involuntary. Both are feared and abhorred. It is not so much the loss of income but the loss of work-mates and of an abiding interest in life.

\subsection{Work and Leisure}

Most leisure activities require money -for transport, for travel, for tools and equipment to pursue the arts, sports, gardening and other DIY activities. Moreover, they are only easily affordable with public provision -of transport, sports facilities, allotments, museums, galleries and concert halls. The individualistic view of welfare which sees individuals living on their own savings to follow their own pursuits irrespective of others is a narrow one; and Mr Blair's occasional appeal to a communitarian rhetoric finds a wide response. But there must be substance in the promise. There can be no community without some shared finance and shared services which are universal and not divisive and exclusive. Much of this can be supplied by voluntary effort, but it needs a foundation of public provision. And this should be part of the meaning of welfare. Where in the UK we talk about redistributive taxation, on the continent they speak of solidarity taxes.

All the pressure to get people off welfare and into work is quite misconceived, if machines are going to take over more and more of the labour we have now to supply to maintain our livelihood. The evidence supplied by expert opinion is that a working life of 1000 hours a year is likely within two or three decades. Already the average in Germany is 1500 compared with 1900 in the UK. The concern with finding paid work for all who want it is not misplaced, but the single minded concentration on work for work's sake and for some supposed competitive advantage is mistaken. The UK has the longest average hours of work of any European country. A tax framework that assists the sharing of work is what is required, not pressure to get everyone into work regardless. 


\subsection{The Limits of the Nation State}

The weakening of the nation state creates more serious problems for the future of welfare than any of the other changes. Increasing globalisation of capital accumulation has not destroyed the powers of the nation state, but it has put all but the most powerful states at the mercy of the giant transnational companies which dominate the world's economy. To attract the investment of these companies, each separate state enters a Dutch auction competing to offer the cheapest labour and the least regulated environment. Mr Blair has nailed his colours to the mast in the matter of deregulation. Britain is going to compete, not to have the best social protection, but the lowest taxes for the employer. As we have seen this was already achieved by a Tory Government in 1994. New Labour proposes to build on that, or rather to dismantle social protection still further.

There is a real problem here. So long as each nation seeks to manage its own welfare state, capitalist competition will tend to drive down labour costs. About a quarter of these are indirect. These are charges for social security and vocational training etc. The threat of unbridled competition to such social protection led to the inclusion of a Social Chapter in the Maastricht Treaty, which a Tory government opted out of and New Labour seems reluctant to accept in full. International agreement on social protection is the only answer to a bidding down everywhere of state provision.

A common European commitment to minimum levels of provision is not only imperative for social cohesion, but, as Stuart Holland has for long insisted, it is an economic imperative (Stuart Holland, The European Imperative, Spokesman, 1993). The reason for this lies in the reduced purchasing power of an increasingly unequal economy. High rates of growth and high levels of employment are associated everywhere, according to the UNDP Human Development Reports, with greater equality of incomes. The United States is the great exception. Actual unemployment in the US is masked by the massive prison population, but, more generally, the exception depends on the hegemonic economic and military power which allows the United States economy to draw in the loans and investment of the whole world.

\subsection{Welfare and Social Change}

What was the purpose of Mr Blair's list of changes in the way we live and work, especially in relation to women, when he asks us to agree to the reform of the welfare state'? More women at work means less reliance on a man's wage and pension rights. This should be a 
good thing, but most of the new employment of women is part-time and much of it carries no requirement on the employer (or employee) to contribute to National Insurance -or any other insurance. Mr Blair says nothing about making this requirement universal, although noncontribution is doubtfully legal under the European Social Charter. More divorces strengthens the case for women to have their own pension rights and to have more and not less support as single parents. The attempt to move single mothers from welfare to work by reducing their benefit fails to take account not only of the absence of jobs and of adequate day care provision, but of the lack of insurance cover for women working part-time. Given the very low general level of their wages, there is little or no possibility that they might build up their own insurances.

In this matter as well as in the larger question of the state pension, the view of the new government seems to be that individuals -men and women- should now make their own individual private insurance arrangements against unemployment, sickness and old age. We are back to the Nineteenth Century with a vengeance. The fact that all incomes are higher now than then does not help the poor, for whom modern living in apartments and estates implies central heating, refrigerators, washing machines, packaged food and transport to the nearest shop, whose price is set by the average buyers and not by the poorer ones. Higher inomes, as we observed earlier, should imply more rather than less ability to pay taxes to ensure a proper health service and education system for all and the possibility of income redistribution to reduce inequalities.

The assumption by $\mathrm{Mr}$ Blair of frequent job changes is designed to support the idea of a personalised insurance system, which the individual worker can carry with him or her from job to job.

Requiring all employers to contribute to such schemes for parttime as well as full-time workers at appropriate rates would be a big step forward, but such schemes carry with them no element of redistribution by the Government. By contrast, as we have had it under the National Insurance scheme, payments are made progressively up to a point according to levels of earnings, but every one receives the same in benefits and in health and education. Where the scheme failed was that the cut-off point left the richest 20 per cent paying no more than those below them. Had they done so, the crisis of underfunding of the state pension need not have occurred. So we were assured by the leading expert on pensions, Professor Peter Townsend, in the pamphlet which he wrote jointly with Barbara Castle and in the Socialist Renewal pamphlet, New Directions for Pensions, written with Alan Walker (Spokesman, 1995). 


\subsection{The Case for the State Pension}

In their pamphlet, Peter Townsend and Alan Walker foresaw that

'Labour's policy on pensions will set the scene for its entire social and economic policy for five years. Its pension policy will be seen widely as a key indicator of Labour's will to change the unstable, divided and more widely impoverished socicty inherited from 16 years of Conservative free market policics.'

They put forward six arguments in favour of restoring the universal state pension plus SERPS rather than supporting further the increased role of occupational and private pensions with a safety net of a minimum state guarantee, which would inevitably be means tested. The arguments were first that means tested income support failed to be claimed by one third of eligible pensioners. These are the very people who Mr Blair says the welfare system is failing. So it is, but it is means testing, not the basic pension, they are refusing. Secondly occupational, private or personal pensions are of little or no use to those, especially women, without full-time labour market careers. Thirdly, only a universal public provision can give economic security in an increasingly flexible and insecure labour market (indeed Townsend and Walker argue that a basic pension will actually assist flexibility). Fourthly, a universal state pension minimises inequalities between older men and women. Fifthly, it is the cheapest form of pension to administer $-1 \mathrm{p}$ in the $f$, compared with $11 \mathrm{p}$ on means tested income support and $25 \mathrm{p}$ or more on private pensions, with all the possibilities we have seen of mis-selling and other abuse. Finally, its very universality and equitable basis enhances social cohesion and solidarity between the generations.

The cost of increasing the basic pension in line with earnings was calculated by Townsend and Walker at 0'4 per cent of annual GDP and for the restoration of SERPS a further 0'8 per cent of GDP. According to John Hills in a Joseph Rowntree Foundation Inquiry, the combined costs of these two over the next 50 years would come to less than a quarter of the cost of the 1992-5 recession. They would, moreover, be offset by reductions in the need for means-tested income support and other contingent benefits. The extra money would have to be found from raising the ceiling for National Insurance Contributions, raising the rate for highest salary earners, increasing the rate for employers of large numbers of employees, and limiting subsidies in the private sector while tightening up on tax avoidance. It will be impossible, Townsend and Walker believe, to develop a viable pensions policy without European policy collaboration. But that does not mean downgrading the provision in the rest of Europe to the mean levels of the UK. They quote as an example to emulate the Danish Social Pension. This provides the sole pension for four fifths of Danish 
pensioners, and at a level of disposable income after housing costs that is equal to 77 per cent of the average income of the whole population.

- The one exception in Mr Blair's statement about the changes affecting welfare provision is the one about the increase in job instability. The International Labour Office in the chapter entitled 'Is Full Employment Passé?' of its 1996/7 Report quoted a study of job stability by K. Swinnerton and H. Wial in the Industrial and Labour Relations Review for January 1995. This reached the following conclusions from studies of data in the United States and in the UK:

'The proportion of workers whose jobs will ultimately last zero to three years decreased slightly from 31 ' 8 per cent in the $1979-83$ period to $30^{\prime} 9$ per cent in the 1987-91 period. The proportion of those who will keep the same job for four to seven years increased from $14 \mathrm{per}$ cent to 15 per cent over the same period, while the proportion of those staying in their job more than eight years remained stable at 54'I per cent...' Thus they believe that 'the data do not suggest that the entire 1979-91 period was a time of increasing job instability'.

Periods of boom and slump must affect stability, but over a longer period, the ILO's own studies suggested that in France and Germany around 60 per cent of male wage workers can expect to keep their jobs more than 15 years. The proportions are only somewhat lower in the USA and Canada, where we are told flexibility of employment is general. The ILO does not see increased instability occurring in the UK, although there is evidence of this in Spain. 


\section{TOWARDS A NEW MANIFESTO}

The old state pension was part of the universal welfare system devised by William Beveridge in 1942 and introduced by the 1945 Labour Government. Mr Blair says that New Labour's principles are still the same as Beveridge's, but they cannot be the same if he moves the welfare system from a universal system to a fall-back system of minimum guaranteed state benefits. We have seen that private pension arrangements have begun to supply an increasing part of the average pension in the UK, over a third by 1993. Increasing numbers of people who can afford it, take out medical insurance. The numbers of children being educated in Britain at private schools does not decline, indicating a rise in the proportion outside the state system. Payment of fees is now introduced for higher education with a personal loan system for maintenance in place of the old grant system.

Of course, $\mathrm{Mr}$ Blair is right to identify the changing structure of family life as affecting al1 welfare provision. The Beveridge system was based on the assumption that the man's wage supplied the contributions to ensure protection for wife and family in the event of sickness, unemployment and old age. The facts Mr Blair attests: that most women now work, though not necessarily, as we have seen, being covered by National Insurance; that the nuclear family is almost the exception and not the rule; and above all that women have won much greater independence, means that this aspect of the system needs to be changed. Individuals and not families need to be insured and guaranteed basic rights of social protection in a society where the overwhelming majority of both men and women can only get a living by selling their labour to a private employer.

The conclusion from all this, however, does not follow that it should be left to the individual to make his or her own best bargain and best arrangements. With the support of strong trade unions that might be more acceptable, but Mr Blair does not appear to be enamoured of strong trade unions, and the unions share with the nation state the weaknesses of being open to division and conquest by the international employing companies. The nation state, or the wider association of states today, still carries the responsibility to ensure the basic civil rights of all citizens and not just minimum rights for those who are excluded from the main stream of national life.

Abandoning universality in welfare must imply means testing and a steady differentiation in the services supplied. It can only mean a perpetuation of the inequalities that have grown under past Tory governments to make the UK the most inegalitarian of all the states of Western Europe through both cutting benefits and undermining wage 
levels with the abolition of the Wages Councils. But inequality means also persisting poverty. And poverty, as the UNDP Human Development studies reveal, is associated with a general lowering of human development. After Ireland and Spain, the UK has the largest proportion of its population in poverty of all Western European countries. From being third in rank in West Europe according to the UNDP's Human Development Index in 1960, it has fallen to ninth place, and in the world league from fifth to fifteenth (Table 3).

Yes $\mathrm{Mr}$ Blair we need reform to meet people's changing work styles, but not if that means dismantling what still exists of the social insurance system and keeping the iniquitous taxation arrangements.

Reform of the welfare state requires the most comprehensive official examination of the costs and benefits of the present system, not selective quotations from the statistics to justify a programme of cuts, laced with exhortations to self-improvement. Unofficially, this has already been done in John Hills report on Income and Wealth for the Joseph Rowntree Foundation in 1995. If it needs to be updated, the Department of Social Security and the Inland Revenue will have all the figures

TABLE 3: Human Development Index (HDI) and Poverty, 1960, 1980 and 1994. European Countries in HDI order 1994.

\begin{tabular}{|c|c|c|c|c|}
\hline \multirow[b]{2}{*}{ Country } & \multicolumn{3}{|c|}{$\begin{array}{l}\text { Human Development Index } \\
\quad(\text { maximum }=1.000)\end{array}$} & \multirow{2}{*}{$\begin{array}{c}\text { Population in Poverty } \\
\% \text { under } \$ 14 \text { a day } \\
1989.94\end{array}$} \\
\hline & 1960 & 1980 & 1994 & \\
\hline France & 0.853 & 0.895 & 0.946 & 12 \\
\hline Norway & 0.865 & 0.901 & 0.943 & 3 \\
\hline Netherlands & 0.855 & 0.888 & 0.940 & 14 \\
\hline Finland & 0.811 & 0.880 & 0.940 & 4 \\
\hline Sweden & 0.867 & 0.899 & 0.936 & 5 \\
\hline Spain & 0.636 & 0.851 & 0.934 & 21 \\
\hline Austria & 0.797 & 0.880 & 0.932 & --- \\
\hline Belgium & 0.826 & 0.873 & 0.932 & 12 \\
\hline UK & 0.857 & 0.892 & 0.931 & 13 \\
\hline Switzerland & 0.853 & 0.897 & 0.930 & --- \\
\hline lreland & 0.710 & 0.862 & 0.929 & 37 \\
\hline Denımark & 0.857 & 0.888 & 0.927 & 8 \\
\hline Germany & 0.841 & 0.881 & 0.924 & 12 \\
\hline Greece & 0.573 & 0.839 & 0.923 & --- \\
\hline Italy & 0.755 & 0.857 & 0.921 & 2 \\
\hline Luxemburg & 0.826 & 0.869 & 0.899 & 4 \\
\hline Portugal & 0.460 & 0.736 & 0.890 & $\cdots$ \\
\hline
\end{tabular}

Notes: HDI is a composite index composed of three variables: life expectancy, educational attaintment (adult literacy and combined primary, secondary and tertiary enrolment) and real GDP per capita in (in PPP\$).

Sources: UNDP Human Development Report, 1997, Annexe Table A.2.1. and p. 53 and Table 5, p. 158 
which are required to find out who pays and who gains, who could pay more and who should receive more. Before any further cuts are made, we need to know all the facts. But we need also to have an open discussion involving independent experts with the power to reveal all the facts in the UK and in other countries, especially those in the European Union, and with the authority to publish them, so that the people of this country can discover what has been done to them and what will be done, unless the direction of welfare provision in Britain is radically changed to reduce inequalities in society instead of perpetuating them.

\subsection{A Labour Movement}

The idea of a Labour Movement in Britain is a very old one. It reflects the historic links between the trade unions and the Labour Party. It appears that these links are finally to be severed by New Labour. As this Manifesto is being written, the TUC General Council has returned from a meeting with the Prime Minister in Downing Street and the news is that Mr Blair will not provide the promised recognition in law for trade unions in establishments where a "majority among the relevant workforce' votes for it. Today no more than $20 \%$ of private sector employees belong to a union and collective bargaining covers less than $50 \%$ of the workforce. It is, as John Monks, the TUC General Secretary said, 'a defining moment'. After almost two decades of Conservative Government onslaught on their rights and privileges, the unions expected support from a New Labour government. It seems that they are not to get it.

The implications of this decision are enormous. The protection of men and women under the social security system, when they are out of work through sickness, unemployment or old age, which has been the subject of this Manifesto, cannot be separated from the protection that workers look to from their unions when they are in work. Some unions have been criticised for their lack of concern for the unemployed and the retired, but they have always assumed that this was the Responsibility of the political wing of the Movement. Without that, the position of labour in Britain in relation to the power of capital is severely weakened. What has been done to working people in two decades in the destruction of great industries without measures to create new employment and in the dismantling of the welfare state has amounted to a massive act of violence against whole communities, leaving in its wake a tide of bitterness and despair.

The virtual annihilation of the Tory Party in Labour's electoral victory a year ago was a collective act of revenge and an expression of 
hope and of faith that change was possible. It seems that that hope and that faith are to be betrayed. It is not just that the government of New Labour is neutral between capital and labour. Mr Blair before the election promised no favours for either. In the event it is the owners and managers of capital who have received the favours. Big business men, both industrialists and bankers, have been brought in by the Government to represent it in key positions, as in the negotiations with the European Union, and to head up QUANGOs and important inquiries into future policy. These include most particularly the review of taxes and benefits for the Chancellor by Sir Mark Turner of Barclays Bank. The traditional conservatism of the Treasury concerning all extensions of public spending and taxation has been constantly reinforced by the pressure of Big Business leaders including the moguls of the media.

\subsection{The Philosophy of New Labour in a Changing World}

The Independent Labour Network has maintained from the beginning that New Labour is not simply following where the last Conservative Government led, in dismantling the welfare state and destroying trade union power, but has its own particular philosophical position. New Labour spokesmen and women deny that the old battles of capital and labour are any longer relevant. They have returned to revive a still older struggle, that between the individual and the state. This is in response to three major changes in social relations in the last decades. The first is that a sizeable minority of the population, without inherited ownership of land or capital, have achieved through their intellectual, artistic or athletic skills a degree of financial independence that makes them unresponsive to traditional collective organisation. A new spirit of individualism has begun to spread through society, stimulated by the media of press and television which reflect the advertising power of the giant manufacturers and retailers of consumer goods and services. This individualism has found its own expression in the burgeoning informal economy and increasing lawlessness where the great industrial communities of the past have been destroyed.

The second change in social relations, which has greatly reinforced the first, is the rightful demand of women for economic and legal independence. The strongest case against the old welfare system is that it was based upon the male earner's income and social insurance contributions to protect his wife and family. After marriage a woman's earnings were regarded as marginal, the wife of an unemployed or sick working man was assumed to be dependent, in old age the woman shared the man's pension -at a lower rate for a couple than for two individuals. When Harriet Harman cries out against such a system, she carries the women with her. The failure of the new intake of women 
into the House of Commons to vote against the cut in the lone parents' benefit was not just done from cowardice or concern to protect a woman minister, but from a visceral rejection by professional women of a system that had for so long treated them as dependents. This flaw does not necessarily, however, put into question the whole system of social insurance, as we have demonstrated earlier.

The third reason for the abandonment of the collectivism of the welfare state is that the powers of the nation state, which was its foundation, have become suborned almost everywhere to the demands of the giant international accumulations of capital. Mr Blair is right to recognise that small to medium sized states have little power today to maintain tax regimes that are unacceptable to the great transnational companies. They will simply transfer their investments and their profits elsewhere to places where conditions are more favourable for their capital accumulation. This is not entirely a new phenomenon, but the new information technology has made the globalisation of production as well as of finance much more all embracing than before.

\subsection{The Alternatives: Competition or Cooperation}

In these new circumstances, there are two alternatives for a medium sized state like the United Kingdom. The first is that chosen by $\mathrm{Mr}$ Blair. That is to seek to make the local economy as competitive in world markets as is possible by offering to transnational capital the most skilled professionals, the cheapest labour, the lowest taxes and the least regulated environment, including trade union as well as physical and ecological controls, of any competing state economy. The drive to move men and women, young and old, able and disabled, out of welfare and into work not only reduces the indirect social protection costs of labour but by increasing the supply of labour lowers its direct price in the market. Mr Blair's constant repetition of the need to be competitive embraces the whole nation but is directed at every individual. Compete or die is the message.

How far Mr Blair and his colleagues actually see what they are doing like that may be doubted, but they are driven by the logic of events, once they have rejected the alternative. Mr Blair employs a communitarian rhetoric and a Christian zeal, but his appeal is to individual self-help. He refers to his policies as following a 'third way' between the extremes of unregulated private capital and of over regulated public ownership. He is right to say that this is the old choice, but his is not the only 'third way'. Indeed his 'third way' is hard to distinguish from the way of unregulated private capital, towards which he is inevitably driven by the power of capital in global markets. 
What then is the alternative which he has rejected? Is there in fact a real alternative that is based on collective action but allows to individuals the freedoms that many have come to enjoy? Or is it in the end indistinguishable from the overregulated totalitarian systems, which have collapsed everywhere? Democratic socialists have undoubtedly failed to make their case and the Blairites have won by default. A powerful argument has been mounted in this Manifesto against the individualist approach to welfare provision, but the collectivist alternative may seem all too similar to what has been rejected in the past. The study of social protection in other European countries which we have made has shown that, in spite of the financial difficulties of surviving individually in a competitive global economy and of the constraints of modelling an Economic and Monetary Union in Europe to compete in that economy, the welfare state outside the UK has survived. Only in Britain has it been cut back to the level of the poorest countries of southern Europe.

That is the first answer, that the welfare state is compatible with democratic government in mixed economies. It also suggests at once the alternative to going it alone in single handed competition to win the favours of international capital. It is to cooperate with others in Europe in defending their welfare states and resisting the power of the giant international companies' attempts to divide and conquer. The opportunity to work together rather than in competition exists. Under Conservative administrations the British people have been held back from taking advantage of these opportunities, but New Labour has given some indication of ending that stance. The possibilities of working together to draw on best practice rather than running a Dutch auction of worsening labour conditions are there to be seized. Harriet Harman in her Guardian article of March 31st 1998 wrote of the consultations that will follow the Government's acceptance of the 'Social Chapter' and its implications for shorter working hours, parental leave and part-time working. It will simply not be acceptable for Britain to continue to force down European wages and conditions of work.

Mr Blair will soon learn, if he does not yet understand, the importance of the collective role of trade unions and of a sense of social security in maintaining the enthusiasm, indeed the very morale, of any workforce. The fact is that the dichotomy between competition and cooperation, between individualism and collectivism is never so sharp in real life as it is drawn by the ideologists. The secret of Japanese economic success hitherto has been the encouragement of competition within a powerful cooperative framework, created, developed and maintained by state institutions. Competing private companies everywhere support professional and technical insitutions for the 
exchange of information about new research and development. The organisation of giant companies is less and less based upon hierarchies of command and increasingly upon networking between decentralised independent profit centres. Mr Blair in extolling individual self-help knows that in every enterprise, public or private, competitiveness has to be moderated by teamwork. We noted earlier how the Green Paper on welfare reform, in the middle of a rhapsody on individual self-help, appealed for the public service ethos in the delivery of welfare.

\subsection{Social Provision that is also Individual}

The conflict in human thought and action between the individual and the collective, between competition and co-operation, between rational calculation and mystical faith, is as old as recorded time. But for a thousand years it was fought out between individualist secular capitalism and a universal hierarchical church. The state has been the battleground sometimes captured by the Church (not only Catholic but also Communist); increasingly in recent years by capitalism. The modern welfare state was, however, created in response to a new force in world history -that of labour, struggling against both capitalist and bureaucratic power. Collectivity did not need to be based upon mysticism but could have firm scientific foundations. It was nation states that had supported the development of capitalism and it was to the nation state that the disinherited turned for protection. Even the workers' trade unions had first to win state recognition to be effective in defending their members' jobs and conditions of work. And from recognition they had moved under Labour Party leadership to make a challenge to capitalist power.

Today this challenge has been checked. This began with an open offensive by a government of the radical Right which started dismantling the welfare state and using unemployment as a tool of monetary management. It has been continued by New Labour in a less open manner, converting the welfare state from a universal source of solidarity into a safety net for those who can prove a 'genuine need' for what are offensively called 'hand-outs', and relegating full employment to second place after the value of money.

The challenge to capital by labour is transmuted into the promise of participation, with labour as the junior partner. The Unions' power is still to be firmly circumscribed, while business is given free rein. Working people whatever their endowment are to make their own way in the market. They will be divided and defeated if they do not find ways to unite in collective defence of the welfare state, with appropriate amendments to recognise the equality of women and the importance 
of part-time work; and in defence of the fundamental human right of a worthwhile occupation for all men and women.

The Independent Labour Network has argued in this Manifesto that no amount of preparation for work of young men, young mothers, long term unemployed or the disabled will be of any avail, if there are no jobs to be had at the end. The task of government has to be not only to provide advice and training and education, a service of health and protection for the disadvantaged; it must also be prepared to create employment. It is an ironic tragedy, which we have already recognised, that just when the main body of economic thought is moving back towards the conviction that full employment is a proper and possible aim of government policy, Mr Blair should be continuing to rely on the market to create jobs. Welfare into work is a splendid slogan if the work is being made available, and the work that needs to be done in our society is unbounded -in clearing up pollution, in recycling waste, in insulating houses, in creating and maintaining parks and leisure facilities, and above all in providing opportunities for lifelong learning.

All these issues crystallised in the European Appeal for Full Employment, which was launched in 1996. It attracted the support of over 600 parliamentarians, including more than 160 Members of the European Parliament, as well as hundreds of trade unions, church bodies and other non-governmental organisations concerned with social questions. The Appeal formed the basis for the first European Convention for Full Employment. This brought together nearly a thousand participants at the European Parliament in Brussels in May 1997. The second Full Employment Convention is planned to meet in Brussels in November 1998.

This Appeal (printed below) has proved capable of uniting socialists of different schools with the main green parties in Europe and other independent radicals in joint and common action. It has done this on the basis of its appreciation of the changing patterns of work in modern society, as well as the continuing humanistic recognition that full employment remains the very foundation of a free society.

\subsection{Full Employment: A European Appeal}

'In Europe today we live in a rich world. Yet our societies are deeply flawed. Millions of our fellow citizens seek paid work and cannot find it: many more than the 20 million officially unemployed. Many women, and many older men have given up the search. In some regions, among our young people, one in five cannot find paid work. In regions of high unemployment, up to half the young people are without employment. More than half of the unemployed have been without 
employment for over a year, and half of these even for two years or more. Ever more women and men are being excluded from any hope of earning their living by actively contributing to their societies' wealth. The welfare state is cut back, unable to cope with continuous unemployment. In some countries this misery has lasted for fifteen years.

We should call this exclusion from society by its right name: it is a disaster which is destroying people's lives, dissolving the social fabric in which we live and depend on one another, undermining the very foundations of democratic politics. It calls for urgent relief.

Creative work for each individual, personal participation in the production of wealth, and corresponding remuneration, are no less basic human needs than are the needs for food, clothing, and shelter. Unemployment generates insecurity and despair. Sickness frequently visits those who are unemployed, so that people may find their health undermined at the same time that they face poverty and social isolation.

Unemployment does not just happen. It is man made. Full employment can surely be achieved again, even if it is not the same kind of full employment we knew during the long post-war period in most Western European countries. Instead of guaranteeing a «family wage» to the male wage earners, leaving other necessary work to be done by women as unpaid work, full employment will now be about guaranteeing access to properly paid work to every independent member of society, thus furthering the redistribution of unpaid work in a fair and better way. And rather than relying on a continuous expansion of every kind of material production, full employment will now have to be based on careful stewardship of natural resources and decent environmental conditions. Since Western European societies are at least three times richer than they were at the birth of post-war welfare politics, we could, in fact, afford to achieve such a new kind of full employment -by supporting an ecologically sustainable recovery, by redistributing paid (and unpaid) work, as well as through private incomes and public goods.

Every where there is a need for public provision of shared services. No one doubts the usefulness, for example, of our caring services, or preventive health work, or of education and training. Why should we not also co-operate in restoring run-down areas, in recuperation of the natural environment, in improving housing security and energy efficiency, in developing sheltered housing for old people, or in offering better child care support, and sport and leisure centres for the young? Is there not equal benefit in support for small and medium enterprises, or for sustainable agriculture? Yet vital services are allowed to decline and decay in a destructive spiral. Public expenditure is reduced, instead 
of reducing public waste and tax fraud. At the same time, new technologies and methods of organisation are used to lay off ever more people, instead of offering them a role in a better network of public provision, and creating more, better qualified and better paid jobs.

Capital movements, all kinds of speculation and even production itself, are now more than ever arranged on an international, global scale. National governments have been set against each other, and trade unions and the working people of each country have been dragged into an economic war for competitive advantage. The arguments supporting this harmful process are misleading: in general, the rate of profitability in Western Europe is far above the global average, and even in countries which are at the forefront of world competition there are real alternatives to the kind of monetaristic policies currently being imposed.

The European Commission and Council of Ministers have launched various plans and proposals over the last few years to create large numbers of jobs all across the Union. But from the launch of the Delors White Paper to the Conclusions of the Essen Summit, in spite of a modest economic recovery in the meantime, the number of people in work has not risen. Throughout Western Europe, the numbers employed remain at least 16 million below what they were in 1990. At the same time, improvements in the number of women finding jobs in parts of the economy are marred by the insecurities of part-time work, and by severely exploitative low pay, while there has been a marked fall in male full-time jobs. The pattern of working time is still organised according to traditional roles for men and women, without adequately recognising the profound changes that have already taken place. Continued large increases in productivity mean that working hours overall can, and should be cut, without the reduction of the resources allocated to pay. At the same time, new fiscal policies could help safeguard earnings and income levels. Indeed, we now face the danger that unemployment and poor jobs will increase, as governments cut back their spending to meet their very restrictive interpretation of the terms of the Maastricht Treaty for a single currency. Now, in many countries, we face a combination of social cuts with the removal of social protection in the labour market. A new misery threatens: the descent into poverty of those who have been long excluded, and of those others who now endure painfully low wages, saps the confidence and strength of their neighbours, and brings fear and insecurity to large parts of Europe.

This European crisis is replicated throughout the world, and we seek allies in every continent to work out employment policies based on co-operation rather than raw competition. 
There is no case for a fortress economy, either at the level of Europe, or at the levels of a nation, a region, or a family. Some have tried: the rich in some countries fortify their suburbs, carry guns and teach their children to shoot. This will not work. The only way forward is to act together, each for all, striking a «new deal» from below, between the poor and the better-off, using the instruments of public policy to advance common interests capable of stabilising broad popular alliances. At local, regional, national and European levels, we need joint and common action to create and to safeguard sufficiently wellpaid jobs, and to re-distribute working time.

We have to persuade a broad majority of the people that it is better to finance socially useful and ecologically sustainable work than to subsidise unemployment. We want to press for a common European economic strategy to reduce unemployment, exclusion, and poverty on the way towards a new era of full employment. This choice involves a wide variety of public and private programmes, including a European level of borrowing and funding, and sustained efforts to reduce working time, share work, and make possible a rich programme of lifelong learning, while at the same time safeguarding the income levels of the working population.

New technologies and new management systems need fewer workers to produce more goods and services. Labour is, in fact, saved this way. We need, however, to use this saved labour in a new sharing of paid and unpaid labour, reducing the gap between those who are overworked, and those who are excluded from society's work, as well as using some of the additional earnings for funding the creation of jobs in the environment, education, and the caring services. Voluntary bodies, churches, and trade unions have already begun to study the effect of sabbatical leave for parents, the provision of training and schooling in working time, and other relevant methods of sharing work, as well as creating humane and satisfying forms of work to replace much labour that is boring and repetitive drudgery.

This Appeal seeks to encourage all forms of action and all modes of employment which will end the disaster of unemployment. Its signatories will seek ways to come together to exchange ideas, examine experiences, and co-ordinate their work. We shall seek to encourage relevant action in the political field, so that employment takes its place at the top of the agenda. We shall also do whatever we can to influence our neighbours and communities to refuse a Europe of exclusion and mass unemployment. Europe must include all its citizens, and afford to each the space in which to develop his or her capacity for happiness and social solidarity.' 